$\begin{array}{lll}\text { KULTURA } & \begin{array}{l}\text { POLSKA A KADEMIA NAUK } \\ \text { KOMITET SOCJOLOGII }\end{array} & \text { ISSN 0023-5172 } \\ \text { i } & \begin{array}{l}\text { INSTYTUT STUDIÓW POLITYCZNYCH } \\ \text { SPOLECLENSTWO }\end{array} & \\ \text { 2016, nr } 3 \quad \text { TRUDNE RELACJE } & \end{array}$

ZOFIA KINOWSKA, ADAM KĘSKA

Instytut Studiów Politycznych PAN

\title{
ROLA PIECZY ZASTĘPCZEJ W PROCESIE SOCJALIZACJI*
}

Podejmujemy tu analizę systemu rodzinnej pieczy zastępczej, ze szczególnym uwzględnieniem jej funkcji prospołecznej rozumianej jako pewna forma funkcji socjalizującej. Ma ona fundamentalne znaczenie w wychowaniu dzieci trafiających do rodzin zastępczych. Polega bowiem na przekazywaniu pożądanych społecznie wzorów zachowań. Dzieci te zazwyczaj pochodzą ze środowisk dysfunkcyjnych. Od stopnia funkcjonalności systemu pieczy zastępczej, w tym zwłaszcza od tego, w jakim zakresie realizuje on funkcję prospołeczną, zależy to, czy w dorosłym życiu dzieci powielą owe niepożądane wzory wyniesione $z$ domu rodzinnego (zjawisko dziedziczenia stylów życia i statusu społecznego) (Domański, Mach, Przybysz 2008, s. 97-132), czy też wyrosną na samodzielnych i praworządnych członków społeczeństwa. Przedstawimy wstępne wyniki badań terenowych przeprowadzonych z reprezentantami poszczególnych podmiotów systemu pieczy zastępczej.

\section{CHARAKTERYSTYKA SYSTEMU RODZINNEJ I INSTYTUCJONALNEJ PIECZY ZASTĘPCZEJ}

Obowiązujący system pieczy zastępczej jest stosunkowo młody, wprowadzono go w roku $2011^{1}$. Zakłada stopniowe wypieranie form instytucjonalnych

Adres do korespondencji: kinowska@isppan.waw.pl; keska@is.uw.edu.pl

* W artykule zostały wykorzystane wyniki roboczego opracowania: „Instytucja pieczy zastępczej — raport z badań wstępnych" (Danecka i in. 2016).

${ }^{1}$ Ustawa $z$ dnia 9 czerwca 2011 r. o wspieraniu rodziny $i$ systemie pieczy zastępczej (tekst jednolity: Dz.U. 2011 nr 149 poz. 887). 
na rzecz rodzinnych. Proces ten jest sukcesywnie realizowany i jest to kontynuacja wieloletniego trendu (zob. Kolankiewicz 2006, s. 15). Ocenia się to pozytywnie. Doświadczenia innych krajów bezsprzecznie wskazują bowiem, że rodzina zastępcza jest najbardziej korzystną formą opieki, jaką można zapewnić dzieciom potrzebującym tymczasowego środowiska opiekuńczego (Gudbrandsson 2006). Jak wynika ze specjalistycznych analiz, piecza zastępcza jest najlepsza przede wszystkim z pedagogicznego punktu widzenia, ponieważ „daje szansę na powstanie więzi osobowych i stworzenie dziecku stabilnego środowiska wychowawczego" (Ruszkowska 2013, s. 17). Jest to jednocześnie najmniej restrykcyjna forma opieki alternatywnej. Dzięki jej elastyczności może być dostosowywana do indywidualnych potrzeb dziecka. Jest wreszcie stosunkowo tania. W literaturze przedmiotu można znaleźć sporo analiz poświęconych zagadnieniom związanym $z$ reformą polityki pomocy społecznej skierowanej do rodzin generalnie i dotyczących pieczy zastępczej w szczególności (zob. m.in. Trawkowska 2011; Hrynkiewicz 2006; Racław-Markowska 2005). Nie ma natomiast dotychczas kompleksowego źródła wiedzy na temat podopiecznych tego systemu w Polsce, danych dotyczących warunków ich życia, rozwoju, nauki ani, co ważniejsze, mówiących o tym, jak odnajdują się w dorosłym życiu. Brakuje także analiz dotyczących funkcjonalności samego systemu.

Dzieci trafiające do pieczy zastępczej zazwyczaj pochodzą ze środowisk dysfunkcyjnych, $z$ tzw. zasiłkowych rodzin patologicznych. Jednak zgodnie $z$ ustawą priorytetowym celem opieki instytucjonalnej jest stworzenie warunków umożliwiających powrót dziecka do jego rodziny biologicznej, aby mogło wychowywać się $\mathrm{w}$ swym naturalnym środowisku ${ }^{2}$. Przyjmuje się zatem, że zła sytuacja rodzinna jest przejściowa i krótkotrwała. Kontakt dzieci z rodzicami biologicznymi nie jest obwarowany szczególnymi warunkami, a prawa i obowiązki wobec dzieci są podzielone między rodziny biologiczne i zastępcze. Do adopcji kieruje się wyłącznie te dzieci, których sytuacja rodzinna nie rokuje poprawy.

Kompetencje w zakresie organizacji pieczy zastępczej i wsparcia rodzin podzielone są między wszystkie szczeble samorządu terytorialnego. Na poziomie gminy podejmuje się współpracę z rodziną biologiczną. Ośrodki Pomocy Społecznej (OPS) zatrudniają tzw. asystentów rodziny. Ich zadania polegają na pracy z rodziną biologiczną, pomocy w wychowaniu dzieci, motywowaniu jej do wysiłku, aby dzieci mogły pozostać w domu. Poziom powiatu jest kluczowy, gdyż to Powiatowe Centra Pomocy Rodzinie (PCPR) najczęściej są organizatorem pieczy zastępczej (także instytucjonalnej). PCPR zatrudnia koordynatorów pieczy zastępczej, którzy spajają cały system: odpowiadają za kontakt opiekunów zastępczych z rodziną biologiczną, z rodziną adopcyjną, z sędziami i z asystentami rodziny. Na poziomie województwa podejmowane są decyzje

2 Tamże, art. 33. 
o adopcji, czyli następuje negatywne (zgodnie z duchem ustawy) zakończenie pieczy zastępczej. Na tym poziomie funkcjonują ośrodki adopcyjne, regionalne placówki opiekuńczo-terapeutyczne oraz interwencyjne ośrodki preadopcyjne.

Ważną rolę pełnią organizacje pozarządowe, które między innymi wspierają organizatora pieczy zastępczej, prowadzą rozmaite szkolenia dla rodzin biologicznych i zastępczych. Same mogą też być organizatorem pieczy. Elementem systemu są również sądy rodzinne, które podejmują niektóre decyzje dotyczące losu dzieci w pieczy zastępczej, na przykład o odebraniu praw rodzicielskich, skierowaniu do adopcji czy o przydzieleniu rodzinie asystenta.

System jest zatem dość skomplikowany. Do jego dobrego funkcjonowania niezbędna jest współpraca wszystkich zaangażowanych podmiotów, a zwłaszcza rodzin biologicznych i zastępczych. Ustawa zakłada, że będą one ze sobą współpracowały, koncentrując się zawsze na dobru dziecka. Duże znaczenie ma także interdyscyplinarna kooperacja między różnymi instytucjami tego samego szczebla samorządu terytorialnego (szkoła, policja, służba zdrowia, kuratorzy sądowi, pracownicy socjalni, asystenci rodziny), która jest warunkiem powodzenia działań na rzecz rodzin i dzieci w środowisku lokalnym.

Ustawa przewiduje dwie podstawowe formy rodzinnej pieczy zastępczej rodzinę zastępczą i rodzinny dom dziecka ${ }^{3}$. Można wyróżnić trzy typy rodzin zastępczych. Pierwszy to rodzina spokrewniona, przy czym za osoby spokrewnione uznaje się wstępnych lub rodzeństwo dziecka. Rodzina zastępcza może być także zawodowa (pogotowia rodzinne i zawodowe specjalistyczne dla dzieci niepełnosprawnych) lub niezawodowa (ale niespokrewniona $z$ dzieckiem). W roku 2012 w całej Polsce było 39,7 tys. jednostek pieczy zastępczej, w tym $225(0,5 \%)$ rodzinnych domów dziecka (GUS 2013). W jednostkach tych żyło około 80 tys. dzieci. Ponad połowa tej grupy — około 58 tys. dzieci umieszczonych było w rodzinach zastępczych zawodowych i spokrewnionych. Większość rodzin zastępczych stanowiły rodziny spokrewnione $-65,1 \%$ ogółu, dalej rodziny niespokrewnione $-30,3 \%$ i rodziny zastępcze zawodowe $4,6 \%$. GUS podaje również, że począwszy od roku 2005 rośnie znaczenie form rodzinnych. Spośród wszystkich dzieci objętych wówczas opieką zastępczą (70 tys.) w rodzinach zastępczych przebywało $71 \%$, a w 2012 roku objętych tego typu pomocą było $75 \%$.

Przedmiotem naszych badań są wyłącznie rodziny zastępcze niespokrewnione oraz rodzinne domy dziecka. Interesuje nas sytuacja, gdy dziecko przebywa nie u krewnych, ale u obcej, wykwalifikowanej rodziny. Jest to najbardziej interesujące socjologicznie, gdyż wtedy opiekunowie zastępczy przekazują wychowankowi inny wzór życia niż ten wyniesiony z domu rodzinnego. Jednocześnie dziecko utrzymuje przeważnie dość regularny kontakt z rodzicami biologicznymi. Taka sytuacja może być przejściowa, jeśli rodzice utracą prawa

3 Tamże, art. 39. 
rodzicielskie i dziecko trafi do adopcji, a może być - i często tak właśnie jest — długotrwała. W każdym razie jednoczesna obecność w życiu dziecka opiekunów i rodziców biologicznych może być źródłem problemów, jeśli współpraca między nimi nie przebiega w sposób optymalny.

Przyjęliśmy, że rodzina jest systemem, który realizuje wiele funkcji. W literaturze przedmiotu znajdziemy różne ich klasyfikacje (zob. np. Ziemska 1977; Tyszka 1979; Hałoń 1995; Szlendak 2012). W przypadku przekazania dzieci do pieczy zastępczej poszczególne elementy systemu pieczy przejmują realizowanie tych funkcji. Dzielą się nimi lub muszą je pełnić wspólnie. Z funkcjonalnego punktu widzenia zatem system pieczy stanowi rozszerzenie systemu, jakim jest rodzina.

Na podstawie przeglądu istniejących klasyfikacji proponujemy wyróżnić następujące grupy realizowanych funkcji. Należy zaznaczyć, że typologia ta pozwala na wydzielenie funkcji prospołecznej, która jest kluczowa z punktu widzenia naszych badań:

1. Funkcja usługowo-opiekuńcza, czyli najbardziej oczywiste zadania związane z podstawową opieką, takie jak żywienie, dbanie o czystość i higienę, o zdrowie, a także zaspokojenie potrzeby troszczenia się o innych.

2. Funkcja materialno-ekonomiczna polega na zapewnieniu utrzymania i zaspokojeniu potrzeb materialnych, chodzi więc o zaopatrzenie dziecka w jedzenie, ubrania, zabawki, a także opłacanie leczenia czy zajęć dodatkowych.

3. Funkcja edukacyjna jest związana $z$ przekazywaniem wiedzy o świecie, innych kulturach, przyrodzie itd. Jej wypełnianie polega między innymi na rozmawianiu, wyjaśnianiu świata w życiu codziennym, wspólnym uczeniu się, czytaniu książek, oglądaniu filmów, zabieraniu dziecka na wycieczki w plener czy do muzeum.

4. Funkcja statu sow a polega na określeniu pozycji w strukturze społecznej, na przykład poprzez przekazanie wzorca wykształcenia czy stylu życia.

5. Fu n kcja e mocj on al na to grupa zadań związanych z wyższymi, trudniejszymi do zaspokojenia potrzebami dziecka. Obejmuje zapewnienie poczucia stabilizacji, możliwości wymiany emocjonalnej, ekspresji uczuć, zaspokojenie potrzeby zrozumienia i uznania. W przypadku dzieci w pieczy zastępczej wchodzi w grę także neutralizowanie traumy związanej ze zmianami domu i opiekunów.

6. Funkcja prospołeczna definiowana jest tu jako specyficzna forma funkcji socjalizującej. Obejmuje ona przekazywanie pożądanych społecznie wzorów zachowań. Składają się na nią działania prowadzące do wychowania samodzielnego członka społeczności, skłonnego i zdolnego do podjęcia pracy i innych pożytecznych społecznie aktywności, do samorozwoju oraz do założenia w pełni funkcjonalnej rodziny. Wśród komponentów funkcji prospołecznej można wymienić działania zarówno skoncentrowane na stymulowaniu indywi- 
dualnego rozwoju jednostki, jak i nakierowane na budowę umiejętności społecznych.

Te pierwsze, traktowane jako niezbędny fundament, to:

- budowanie motywacji do samorozwoju i aspiracji życiowych;

- wspieranie rozwoju umiejętności i potencjału jednostki, pomoc w zdobyciu wykształcenia;

- wspieranie rozwoju emocjonalnego i samoakceptacji.

W drugiej grupie komponentów znajdują się:

- nauka samodzielnego funkcjonowania w społeczeństwie;

- przekazywanie wzorców działań pożytecznych społecznie;

— nauka współdziałania i nawiązywania prawidłowych relacji społecznych;

- wpajanie prospołecznych wartości i norm.

Realizacja tej funkcji może mieć formę bierną lub aktywną. Aktywne działanie wspierające rozwój dziecka to sytuacja „normalna”, ale w rodzinach, z których pochodzą dzieci objęte pieczą zastępczą, zdarza się sporadycznie. Bierne wypełnianie funkcji prospołecznej nie polega na bezpośrednim podejmowaniu wysiłków wychowawczych, lecz sprowadza się do nietorpedowania cudzych starań. Wymaga jednak autorefleksji i motywacji, by zapewnić lepszą przyszłość potomstwu. Rodzice muszą chcieć poprawy statusu społecznego i usamodzielnienia życiowego swoich dzieci i sprzyjać wysiłkom rodziny zastępczej idącym w tym kierunku. Bierne realizowanie funkcji prospołecznej polega zatem na zgodzie rodziców biologicznych na przyjęcie przez dzieci odmiennego systemu wartości i norm. Ich wkład obejmuje niegenerowanie sprzecznych z nim komunikatów i niepodważanie autorytetu rodziców zastępczych. W praktyce okazuje się to trudne.

Głównym problemem badawczym naszych analiz jest realizowanie funkcji prospołecznej przez podmioty zaangażowane $\mathrm{w}$ wychowanie dzieci objętych pieczą zastępczą. Na efektywność działań w tym zakresie ma wpływ wiele czynników. Bierzemy pod uwagę przede wszystkim uwarunkowania związane z mechanizmami interakcji poszczególnych elementów systemu. Można je rozpatrywać na dwóch powiązanych poziomach. Pierwszy to poziom założeń leżących u podstaw obowiązujących rozwiązań społeczno-prawnych. Skonfrontowaniu założeń z praktyką służy analiza wewnętrznej konstrukcji systemu, sposobu definiowania celów oraz rzeczywistych możliwości ich realizacji. Drugi poziom odnosi się do realnych konsekwencji dystrybucji zadań rodziny między rodziców zastępczych, rodziców biologicznych oraz przedstawicieli instytucji państwowych.

\section{FUNKCJA PROSPOŁECZNA PIECZY ZASTĘPCZEJ W ŚWIETLE BADAŃ JAKOŚCIOWYCH}

Funkcja prospołeczna stała się przedmiotem badań ze względu na jej znaczenie dla ogólnych procesów: reprodukcji wzorów i dziedziczenia statusu spo- 
łecznego. Najkrócej można powiedzieć, że celem badawczym była odpowiedź na następujące pytania:

1. Czy i jak w ramach obowiązującego systemu pieczy zastępczej realizowana jest funkcja prospołeczna?

2. Co pomaga, a co utrudnia realizowanie tej funkcji w praktyce?

3. Jaka jest skala dziedziczenia patologii? Od ilu pokoleń w rodzinie biologicznej dzieci dziś pozostających w pieczy zastępczej występowały dysfunkcje?

4. Czyj status społeczny dziedziczą dzieci pozostające w pieczy zastępczej — rodziców biologicznych czy zastępczych?

Trzeba zaznaczyć, że przedstawiamy wstępne wyniki dopiero rozpoczętych badań jakościowych. Od wrzesnia 2015 roku do marca 2016 przeprowadziliśmy 21 wywiadów pogłębionych, na razie jedynie w województwie mazowieckim. Badania objęły opiekunów zastępczych oraz przedstawicieli strony instytucjonalnej, w tym Ministerstwa Pracy i Polityki Społecznej jako instytucji kreującej ramy prawne i założenia całego systemu, a także organizatorów i koordynatorów jako instytucje i osoby realizujące założenia systemu pieczy zastępczej w terenie, pracowników socjalnych, asystentów rodzin, przedstawicieli organizacji pozarządowych, które współpracują z organizatorami pieczy zastępczej. Analiza treści wywiadów pozwoliła na dostrzeżenie pięciu charakterystycznych zjawisk.

Konflikt wbudowany w układ organizacyjny

Z wypowiedzi respondentów wynika, że obowiązujący podział funkcji między poszczególnymi aktorami społecznymi nie jest optymalny i generuje konflikty. Wynika to, po pierwsze, z podwójnej roli koordynatorów wobec opiekunów zastępczych, a po drugie $-z$ trudnych relacji między opiekunami zastępczymi a rodzicami biologicznymi dzieci objętych pieczą zastępczą.

Pomieszanie ws parcia z kontrolą. W narracjach respondentów powtarza się wątek pomieszania w roli koordynatorów wsparcia $z$ kontrolą. Są zobowiązani do realizacji sprzecznych zadań: do ich obowiązków należy ocenianie, rozliczanie i decydowanie o dalszym zatrudnianiu opiekuna zastępczego, a jednocześnie mają być dla niego wsparciem, czyli na przykład powiernikiem w trudnościach.

[...] wsparcie ma charakter oficjalny. W praktyce jest tak, że wsparciem się nazywa kontrolowanie. I to [kontrolowanie] jest rozumiane jako wsparcie. [...] Samo mówienie o trudnościach świadczy o tym, że sobie nie radzimy. Czyli lepiej nie mówić o trudnościach, żeby ktoś nie powiedziat, że sobie nie radzimy. [opiekun zastępczy] ${ }^{4}$

\footnotetext{
${ }^{4}$ Wśród respondentów znaleźli się reprezentanci poszczególnych podmiotów systemu pieczy zastępczej. W nawiasie po każdym cytacie znajduje się informacja wskazująca jedną z sześciu kategorii, do której dany respondent został przyporządkowany: opiekun zastępczy, pracownik organizacji pozarządowej, koordynator pieczy zastępczej, asystent rodziny ośrodka pomocy społecznej
} 
Jest tutaj pewne niebezpieczeństwo polegajace na tym, że jeżeli tenże koordynator będzie wchodzit w rolę nadzoru, kontroli, to aspekt wspierania, wsparcia i charakter tej pracy zostanie utracony. I dlatego bardzo ważna rolę przypisuje temu, aby koordynator byt jakby wtaściwie opisany z punktu widzenia zadań, które mu przyświecaja, a wiem, że w niektórych powiatach czasem dzieje się tak, jest taka pokusa, żeby byt on elementem kontroli... [pracownik MPiPS]

Jak podkreślają badani (zarówno koordynatorzy, jak i opiekunowie zastępczy), trudno w takim układzie o zakładaną w ustawie szczerość i wspólne szukanie rozwiązań pojawiających się problemów. Pomieszanie ról utrudnia, jeśli nie uniemożliwia, zbudowanie zaufania i realną współpracę. Opiekunowie zastępczy boją się, że przyznanie się do trudności negatywnie wpłynie na ich ocenę, koordynatorzy zaś boją się, że jeśli nie odnotują w stosownym raporcie trudności, to w razie poważniejszych problemów będą pociągnięci do odpowiedzialności za niedopatrzenie. Efektem wbudowanego w system konfliktu jest brak zaufania i utrudnienie współpracy przy rozwiązywaniu realnych problemów. Respondenci - zwłaszcza opiekunowie zastępczy, przedstawiciele organizacji pozarządowych i koordynatorzy — przyznają, że realna współpraca jest bardzo trudna i dużo jest działań pozorowanych. Nie musi to wynikać ze złej woli, lecz z lęku przed odpowiedzialnością i z błędów systemowych.

Gdyby komuś się udało rzeczywiście wspótpracować z rodzicami i ci rodzice by kogoś obdarzyli zaufaniem, to wtedy by to dato najwięcej rezultatów. Ale wygląda na to, że większość inicjatyw, które byty przedsiębrane $w$ tym kierunku, no, nie udaje się. Nie udaje się i wedtug mnie główna przyczyna to jest, że jeśli udajemy — ja jako pracownik udaję, że coś robię, a ja jako rodzic udaje, że wspótpracuję, po to aby mi nikt nie zarzucit, że nie wspótpracuje, no to to się nie może udać. [opiekun zastępczy]

Niby w pieczy zastępczej jest teraz tak, że raz na pót roku zbiera się zespót i rozmawia o danym dziecku, ale to jest kolejna fikcja, bo tak naprawdę to się szczerze o tym dziecku nie rozmawia i nie ma wniosków, co dalej. [...] żeby zespót miat rzeczywiste znaczenie, to on musi zaczaćc pracować, tak? A nie że się spotykamy i tak rozmawiamy, żeby nic nie powiedzieć. [...] Bariera lęku. No bo powiesz coś i potem będziesz za to odpowiedzialna. Główna motywacja, która przyświeca, główna, a nieoficjalna, to jest, żeby się nikt nie przyczepił. [opiekun zastępczy]

Rywalizacja zamiast ws półpracy. Nowe tendencje w zreformowanym systemie pieczy uwypuklają relacje między podmiotami zaangażowanymi na najniższym szczeblu. Jak zauważa Mariola Racław (2013/2014, s. 36): „procesy związane $z$ utowarowieniem opieki i częściowo tendencje deetatystyczne (uruchamiane w strukturze obsługi sfery publicznej, w tym wzrost znaczenia konkurencji) wprowadzają inny rodzaj powiązań — relacje (oparte na wymianie równych wartości) nie tylko między administratorami usługi opieki, ale także między jej wykonawcami i beneficjentami". Przypomnijmy, że powrót dziecka

(OPS), pracownik socjalny ośrodka pomocy społecznej (OPS), pracownik Ministerstwa Pracy i Polityki Społecznej (MPiPS). 
do rodziny biologicznej został uznany za priorytet. Ten postulat oraz przydzielone rodzicom biologicznym prawa i obowiązki dają im szczególną pozycję oraz czynią problematycznymi ich relacje $z$ innymi podmiotami.

Problem w relacji z rodzicami biologicznymi jest podnoszony przez wszystkich respondentów. Opiekunowie zastępczy mówią o wrogości, rywalizacji i nastawianiu dzieci przeciw opiekunom zastępczym, co stawia je w silnym konflikcie lojalnościowym.

My jesteśmy [dla rodziców biologicznych] wrogami numer jeden. Nie ma wspótpracy ani partnerstwa. A wręcz jest namawianie dzieci, żeby się nam przeciwstawiaty. No bo to jest zagrożenie, tak? Że dziecko wybierze ciocię zastępcza, a nie mnie. [opiekun zastępczy]

$Z$ naszych obserwacji to my, wychowanek i rodzina wchodzimy w jakiś taki trójkąt dramatyczny. Czyli tak: wychowanek jest ofiara, my jesteśmy prześladowcami, a rodzice to sa ratownicy. Bo dzieci mówia rodzicom, jak to jest źle, oni bronia dziecka, czyli nas krytykują, dziecko się czuje lepiej, bo rodzice zastępczy sq krytykowani i wiadomo gdzie jest dobrze, a gdzie jest źle i to wszystko świetnie funkcjonuje. [opiekun zastępczy]

Pamiętajmy, że to nie są nasze dzieci, które nam ufaja, nam wierza, sa z nami związane, tylko to sa dzieci, które sa często bardzo pokiereszowane, a ufają swoim rodzicom i z tego tytułu samego jest tysiące kłopotów. [pracownik organizacji pozarządowej]

Warto podkreślić, że zarysowane konflikty w praktyce oznaczają brak pola dialogu między podmiotami systemu i trudność lub wręcz niemożność wypracowywania strategii współpracy podczas realizacji wspólnych celów, na przykład wspólnego planu wychowawczego. Wydaje się, że stworzenie nowego typu bytu rodzinnego opartego na współpracy rodziny pochodzenia i rodziny zastępczej w obowiązujących ramach systemowych jest niemożliwe.

Rodziny zastępcze pozbawione odpowiedniegowsparcia społecznego i organizacyjnego

Respondenci zwracali uwagę na trudne położenie opiekunów zastępczych, którzy w obowiązującym systemie są obciążeni ogromną odpowiedzialnością i mają bardzo mało realnego wsparcia — zarówno w ramach systemu, jak i poza nim. O trudnościach współpracy wpisanych w relację opiekunów zastępczych $z$ koordynatorami i z rodzinami biologicznymi była już mowa. Osobną kwestią są problemy opiekunów zastępczych w zetknięciu $z$ otoczeniem społecznym, które - jak wynika z relacji badanych - często jest wobec nich podejrzliwe czy wręcz wrogo nastawione. Jest to związane $z$ brakiem wiedzy o specyfice ich pracy oraz problemach ich podopiecznych. Są to dzieci bardzo obciążone i praca z nimi jest niezwykle trudna. Doświadczenia respondentów wskazują, że często nauczycielom czy lekarzom brak wiedzy o tym, w jakim stanie dzieci trafiaja do pieczy. Dlatego zdarza się, że zamiast wspomagać opiekunów zastępczych, podejrzewają ich czy nawet obwiniają o to, co z dzieckiem się dzieje. Wynika 
to także $\mathrm{w}$ pewnej mierze $\mathrm{z}$ negatywnego wizerunku rodzin zastępczych, czerpanego z przekazów medialnych.

Szkoty nasze nie sa $w$ ogóle przygotowane na z zaburzeniem więzi, dzieci z FAS. [...] Łatwiej sobie szkołom poradzić z niepetnosprawnościa fizyczna dziecka, z ułomnościami typu zaburzenia wzroku, stuchu, narządów ruchu niż z dzieckiem, które jest agresywne, które nie rozumie relacji społecznych. [...] Tu kompletnie sobie nauczyciele nie radza $i$ ja ich rozumiem, ale gdzieś te dzieci musza realizować obowiazek szkolny. [...] Czasami [szkoła] próbuje przerzucić odpowiedzialność na rodzinę. [...] Ze strony rodziny jest lęk i niepokój, że sa ciagle pod obstrzatem. Zwłaszcza w świetle różnych wydarzeń, które $w$ mediach sa nagtaśniane. [koordynator pieczy zastępczej]

Brakuje nauczycielom wiedzy o tym, jak funkcjonują te dzieci [...] Na przykład to, że jeśli dziecko głodowało, to ono jest w stanie jeść takie ilości jedzenia, że po prostu dziesięć obiadów jest w stanie zjeść [...] Dziecko idzie pierwszy raz do przedszkola i panie się dziwia, Jezu, wyjada z tego talerza i z tego talerza - i co im się rodzi? Nie jest żywione $w$ domu. No i mieliśmy taka sytuacje u znajomych, że nie zapytano ich, jak sa dzieci żywione [...] tylko wezwano tego prowadzacego rodzinny dom dziecka do dyrektora na dywanik, gdzie byt psycholog, pedagog, pani wychowawczyni i byto wręcz „dlaczego pan głodzi dziecko?”. Nie byto pytań, wyjaśnień, tylko byto już oskarżenie $i$ dopiero potem jak ten rodzic zastępczy wyttumaczyt, jak to dziecko funkcjonuje, to to przyjęto. [opiekun zastępczy]

Bardzo często się spotykam z problemem pod hastem: wspótpraca rodziny zastępczej ze szkoła. Bo szkoła mówi: "ta pani jest rodzina zastępcza, pani dostała te 1000 złotych na dziecko, a dziecko nie umie tego, nie umie tego, nie umie - więc niech pani coś z tym zrobi". To nie ta pani, ta pani wkłada swoje serce, trud, przyjęła dziecko pod własny dach, robi tysiace różnych rzeczy, a od edukacji jest właśnie szkoła. Pani opiekunka zastępcza nie musi się znać na edukacji, tym się powinna zając szkoła. Jest bardzo wiele konfliktów. Opiekunowie mają iść do szkoty, to aż im się wtosy jeża często, bo ich spotka tam tylko jakieś ocenianie, to znaczy mówię znowu o większości, bo parę szkót widziatem, które są naprawdę bardzo przychylne dzieciom i wiele rzeczy można załatwić, ale większość... [pracownik organizacji pozarządowej]

\section{Brak współpracy z rodzicami biologicznymi jako źródło frustracji opiekunów zastępczych}

Przystępując do badań zakładaliśmy, że rodziny biologiczne są pozbawione dostatecznego wsparcia w dążeniu do poprawy swojej wydolności wychowawczej. Obraz wyłaniający się z badań jest inny - wydaje się, że problemem jest brak motywacji do zmiany. Można to postrzegać jako błąd systemowy. Roszczeniowa postawa rodziców biologicznych może wynikać z tego, że pomoc i kontakty $z$ dziećmi nie są warunkowane ich postępami w dążeniu do zmiany. $Z$ relacji respondentów wynika, że łatwo adaptują się oni do sytuacji, w której dziecko $z$ nimi nie mieszka, jeżeli mogą je odwiedzać. Taka rozłąka nie motywuje. Wydaje się też, że niedoceniane są opory przed dokonaniem zmiany trybu życia ze strony rodziców biologicznych, którzy sami często pochodzą z rodzin dysfunkcyjnych i byli wychowankami placówek. 
Bo z naszego doświadczenia wynika, że te rodziny się świetnie przystosowują do takiej sytuacji, że dziecko nie mieszka $w$ domu, mieszka gdzie indziej, ale raz $w$ tygodniu się spotykam i jest super. Jest prościej. Jest nakarmione, załatwione. I jeszcze mogę rozliczać kogoś, to nie ja jestem odpowiedzialny, dziecko do mnie lgnie, ja jestem tym dobrym, oni saźli. Po prostu $\dot{z} y c ́$, nie umierać. Z psychologicznego punktu widzenia to jest świetna sytuacja. Oni nie prze$\dot{z} y w a j a, \dot{z}$ e dziecko nie mieszka, że ja nie mam z nim więzi, nie. Świetny układ. [opiekun zastępczy]

Ja widzę największy problem $w$ tym, ̇̇e tym rodzinom się nie chce. One sa wyuczone bezradności, wyuczone korzystania z pomocy społecznej. Obracają się w takich środowiskach, $\dot{z}$ e nie jest wstydem przyznać się, że dziecko trafia do placówki. Dla nich to jest zwyczajne, normalne, oni się tego nie krępują. [...] nie postrzegają asystenta albo pomocy społecznej jako coś, co może im pomóc, żeby się uniezależnić. [...] Czasem na sitę poszukują u tych dzieci jakichś chorób, dzięki którym można uzyskać orzeczenie $i$ świadczenie pielęgnacyjne na to dziecko. Wbrew pozorom te rodziny sa bardzo cwane i nauczone radzenia sobie $w \dot{z} y$ ciu, gdzie pójść [...] Tego się nie uniknie. Nie da się zmienić dzieci bez zmiany rodziców. [asystent rodziny OPS]

P. była tam asystentem społecznym $i$ ona autentycznie miała chęć, żeby pomóc tam. Ale rzeczywiście napotykała mur. No bo jeśli na przykład jak raz tam poszła $i$ zaproponowała, żeby dzieci zaczęły chodzić do żłobka i do przedszkola, które jest tam dwie ulice dalej, $i w$ domu była babcia, mama, konkubent $i$ jeszcze ktoś $w$ tym mieszkaniu i wszyscy orzekli, że dobrze, że może moga je posłać, tylko kto je będzie zaprowadzat, bo oni nie maja czasu. Oni bardzo chętnie, ale jak pani będzie przychodzić $i$ zaprowadzać i przyprowadzać, to oni się zgodza [...] [opiekun zastępczy]

W ogóle konflikty między rodzinami biologicznymi a rodzinami zastępczymi - to naprawdę są nagminne. Bardzo trudno pracuje się wtedy, ciężko jest cokolwiek wyegzekwować $i$ do przodu pójść, bo strasznie to utrudnia pracę. Zreszta, dziecko jest w tym najbardziej pokrzywdzone, bo raz samo nie może się z tym rodzicem dogadać, dwa - że uczestniczy też, najczęściej obserwuje te sytuacje, często kłótni i też awantur rodziny. To jest w ogóle trudna działka. [koordynator pieczy zastępczej]

Warto zaznaczyć, iż respondenci są zgodni co do słuszności założenia ustawy o tym, że dobro dziecka wymaga tego, by było ono z rodzicami, że należy dążyć, by wróciło do swojego środowiska naturalnego. Podkreślają, że „wyprowadzenie na prostą" rodzica to największa szansa dla dzieci. Niestety, w praktyce jest to niezwykle trudne. Według ustawy pobyt dziecka w pieczy jest tymczasowy, co nie znaczy, że trwa krótko. Oczekuje się, by dziecko pozostawało pod opieką państwa, podczas gdy rodzice pracują nad sobą, aby móc przyjąć je z powrotem. Nie ma nacisku na to, by realizować to, co nazywamy funkcją prospołeczną. Dba się natomiast, by utrzymać więź dziecka z rodzicem biologicznym, do którego dziecko ma wrócić, bez egzekwowania od rodziców współpracy w wychowywaniu dziecka w tym „międzyczasie". 
Sprzeczne wzory i poczucie tymczasowości udziałem dzieci w opiece zastępczej

Sposób rozgrywania gry opieki między aktorami tej sytuacji społecznej skutkuje nieprawidłowym wypełnianiem funkcji prospołecznej z powodu sprzecznych wzorów przekazywanych dzieciom i permanentnego poczucia tymczasowości wpisanego w pieczę zastępczą. W narracjach respondentów zalazło się bardzo wiele przykładów sytuacji, w których rodzice biologiczni i opiekunowie zastępczy dają dzieciom sprzeczne komunikaty.

Nasz znajomy chcac wspótpracować z tata biologicznym na spotkaniach mówit o trudnościach wychowawczych, mówit, że ma prośbę, żeby tata z nimi porozmawiał na spotkaniu, żeby coś zrobit, no i tata biologiczny właśnie, jak tamten się dzielit, jakie byty problemy, jakie uwagi $w$ szkole etc., to on otwierat plecaczek i samochodziki wyjmowat i nagradzat chtopców za złe zachowanie w szkole i pizzę zamówił do WCPR-u [Wojewódzkie Centrum Pomocy Rodzinie], żeby chtopcy sobie zjedli. No i tak to wyglada wspótpraca. [opiekun zastępczy]

Rodzicom biologicznym jest łatwiej zaspokoić funkcje materialnq niż emocjonalna. $\mathrm{Na}$ przykład kupić coś, ale nie potrafia zaspokoić potrzeby uznania, zrozumienia. Dzieci z kolei sa bardzo z nimi emocjonalnie zwiazane. Ci rodzice sami maja poczucie krzywdy, która wyrzadzili. [...] To poczucie krzywdy, wstydu często nadrabiaja materialnie. [pracownik socjalny OPS]

Wydaje się, że dzieci w rodzinach zastępczych znajdują się w sytuacji permanentnej sprzeczności i konfliktu zaangażowanych w opiekę podmiotów. W tych warunkach realizacja funkcji prospołecznej wydaje się bardzo trudna.

\section{Nierealizowanie funkcji prospołecznej jakoczynnik reprodukcji patologii}

W obecnym systemie pieczy zastępczej funkcja prospołeczna nie jest realizowana, co może prowadzić do reprodukcji zjawisk patologicznych. Na tym etapie badań nie jesteśmy w stanie ocenić skali tego zjawiska, ale niewątpliwie nie jest rzadkością, że dzieci po osiągnięciu dorosłości wracają do domów rodzinnych i powtarzają wzory życiowe swoich rodzin pochodzenia.

[...] bardzo często kończy się to tak, że te dzieciaki po dorośnięciu nie maja przygotowanego zaplecza do tego, gdzie żyć, z kim żyć, gdzie mieszkać, za co żyć, jak się rozwijać, jakich mieć przyjaciót, jakich mieć partnerów. I bardzo często oni sa tak bezradni po tych kilkunastu latach instytucji, że im nie pozostaje nic innego jak wracać $w$ te środowisko rodzinne. [pracownik organizacji pozarządowej]

To jest bardzo przykre, jak widzę, że trzy lata pracowałam z rodzinq i ta praca nic nie dała, bo dziecko widzi, że życie rodziców jest prostsze, bo niewiele wymaga, więc wracaja do tego [...] To jest sytuacja powszechna. Ze wszystkich rodzin, z którymi ja pracowałam przez te trzy lata, to $w 90 \%$ rodzin patologie lub te tendencje sa dziedziczone. Ciężko jest się wyrwać ze środowiska, w którym się wychowuje. Trzeba naprawdę dużo sity, samozaparcia, 
żeby z tego środowiska wyjść. A te rodziny nie znaja po prostu innego życia. Oni [rodzice biologiczni] byli sami albo $w$ placówkach czy $w$ rodzinach zastępczych, rodzice byli alkoholikami czy narkomanami, $i$ oni teraz sami powielaja te zachowania i przekazuja dalej. [asystent rodziny OPS]

Te dzieci kończa osiemnaście lat $w$ rodzinie zastępczej, usamodzielniają się i koniec. I tak naprawdę nie otrzymują żadnej pomocy. Dostaja od państwa kawalerkę [...] jakaśs kwote na wyposażenie tego mieszkania, odchodza i nikt się nie interesuje, jak sobie dalej radza [...] te dzieciaki wracaja po prostu do domu [...] Tam sie nic nie zmienia i popadaja $w$ to samo, co rodzice. [opiekun zastępczy]

Czy oni przejda własna terapię skierowana na bliskie relacje, związki, na to, jak sobie poukładać życie osobiste $i$ zawodowe, założyć własna rodzinę, czy oni przejda cała sprawę dotyczaca wejścia $w$ ogóle na rynek pracy, na rynek zawodowy, jeszcze się muszą nauczyć gospodarować pieniędzmi. Czy oni się naucza budować trwałe związki z innymi ludźmi, przyjaźnie, związki, w których jest oparcie, jest pomoc, jest wspótczucie, czy oni się naucza korzystać ze świata kultury, czy oni się naucza rozwoju osobistego? Jeśli nie, to samo to bezpieczeństwo i sama ukończona szkoła niczego nie zmienia $w$ ich życiu. [pracownik organizacji pozarządowej]

W narracjach respondentów najczęściej pojawiają się dwa wyjaśnienia tego stanu rzeczy. Po pierwsze, że państwo za mało dba o te dzieci po usamodzielnieniu, że skromnie wyposaża je finansowo i na tym koniec. Tymczasem jest to dalece niewystarczające, ponieważ nie umieją one zdobyć ani utrzymać pracy, nie umieją same o siebie zadbać, więc wracają do rodziców. Drugie wytłumaczenie koncentruje się na problemach natury psychologicznej i niemożności budowania trwałych więzi z innymi ludźmi. To jest powód - jak twierdzą respondenci - dla którego dzieci te wchodząc w dorosłość nie są w stanie zakorzenić się w innym życiu, zwycięża lojalność wobec więzi pierwotnych, bo nie umieją nic innego zbudować. Podkreślany był emocjonalny aspekt funkcji prospołecznej, polegający na przygotowaniu dzieci do budowania zdrowych więzi społecznych, co biorąc pod uwagę trudne doświadczenia życiowe często wymaga psychoterapii. Trzeba jednak pamiętać, że podjęcie psychoterapii wymaga zarówno świadomości swoich problemów, jak i pieniędzy. Być może potrzebny jest osobny program realizowania funkcji prospołecznej na etapie usamodzielniania wychowanków pieczy zastępczej.

\section{WSTĘPNE WNIOSKI Z BADAŃ}

Może się wydawać, że przedstawiamy tu czarny obraz funkcjonowania systemu pieczy zastępczej. Jednak choć wiele da się wskazać niedostatków, nie można stwierdzić, że system ten jest całkowicie niewydolny. Trzeba zdawać sobie sprawę, że ma służyć rozwiązywaniu niezwykle złożonych i trudnych problemów. Niezbędna jest jednak dalsza praca nad jego usprawnieniem. Na podstawie wyników badań można wysunąć wstępne sugestie, co mogłoby pozwolić na zwiększenie wydolności systemu: 
1. Uwzględnienie znaczenia realizacji funkcji prospołecznej.

2. Zrewidowanie zapisów o kontroli i wsparciu w zadaniach koordynatorów pieczy zastępczej oraz asystentów rodziny.

3. Poszukanie sposobów motywowania rodziców biologicznych do zmiany trybu życia, który doprowadził do odebrania im dzieci, i egzekwowanie ich postępów w tym zakresie, zanim dzieci wrócą pod ich opiekę.

4. Profesjonalizacja i docenienie roli opiekuna zastępczego i asystenta rodziny. Te grupy zawodowe cechuje wysoka rotacja. Obciążenia i brak wsparcia powodują rezygnację z pracy, a ludzi do pracy w tych zawodach brakuje.

Podjęty problem niewątpliwie wymaga dalszych badań. Aby można było mówić o specyfikach lokalnych, należy przejść na poziom ogólnopolski. Na podstawie danych jakościowych jesteśmy w stanie stwierdzić, że poszczególne zjawiska występują, ale nie wiadomo, jak często i jaki jest ich zasięg. Pożądane jest zatem uzupełnienie analiz o badania ilościowe.

\section{BIBLIOGRAFIA}

Danecka Marta, Kinowska Zofia, Kęska Adam, Cieślar Jacek, 2016, „Instytucja pieczy zastępczej — raport z badań wstępnych", ISP PAN, Warszawa.

Domański Henryk, Mach Bogdan, Przybysz Dariusz, 2008, Pochodzenie społeczne - wykształcenie zawód: ruchliwość społeczna w Polsce w latach 1982-2000, w: Henryk Domański (red.), Zmiany stratyfikacji społecznej w Polsce, Warszawa, Wydawnictwo IFiS PAN.

Gudbrandsson Braggi, 2006, Dzieci w instytucjach opiekuńczych: zapobieganie instytucjonalizacji i alternatywne formy opieki w krajach europejskich, „Dziecko Krzywdzone”, t. 5, nr 4.

GUS, 2013, Pomoc społeczna i opieka nad dzieckiem i rodzina 2012 roku. Raport, Główny Urząd Statystyczny, Warszawa.

Hałoń Edward (red.), 1995, Rodzina - jej funkcje przystosowawcze i ochronne, CUN PAN, Warszawa.

Hrynkiewicz Józefina, 2006, Odrzuceni. Analiza procesu umieszczania dzieci w placówkach opieki, instytut Spraw Publicznych, Warszawa.

Kolankiewicz Maria, 2006, Zapiski o instytucjonalnej opiece nad dziećmi, „Dziecko Krzywdzone. Teoria, Badania, Praktyka", nr 17.

Racław-Markowska Mariola, 2005, System pomocy rodzinom i dzieciom jako narzędzie przeciwdziałania wykluczeniu w środowiskach lokalnych, w: Lucyna Frąckiewicz (red.), Wykluczenie spoteczne, Wydawnictwo Akademii Ekonomicznej, Katowice.

Racław Mariola, 2011, Kontradykcje opieki zastępczej, w: Dobroniega Trawkowska (red.), Pomoc spoteczna wobec rodzin. Interdyscyplinarne rozważania o publicznej trosce o dziecko i rodzinę, Akapit, Toruń.

Racław Mariola, 2013/2014, O sieciowaniu i granicach pracy (socjalnej) z rodzinami w opiece zastępczej, „Trzeci Sektor,” numer specjalny, s. 35-45.

Roguska Agnieszka, Danielak-Chomać Małgorzata, Kulig Beata (red.), 2011, Rodzinne formy opieki zastępczej. Teoria i praktyka, Stowarzyszenie Wioski Dziecięce-Fundacja „Szansa”-Uniwersytet Przyrodniczo-Humanistyczny, Warszawa-Siedlce.

Ruszkowska Marzena, 2013, Diagnoza rodzin zastępczych w obliczu dylematów wspótczesności, Centrum Rozwoju Zasobów Ludzkich, Warszawa.

Szlendak Tomasz, 2012, Socjologia rodziny. Ewolucja, historia, zróżnicowanie, Wydawnictwo Naukowe PWN, Warszawa. 
Trawkowska Dobroniega (red.), 2011, Pomoc społeczna wobec rodzin. Interdyscyplinarne rozważania o publicznej trosce o dziecko i rodzine, Akapit, Toruń.

Tyszka Zbigniew, 1979, Socjologia rodziny, Państwowe Wydawnictwo Naukowe, Warszawa.

Ziemska Maria, 1977, Rodzina a osobowość, Wiedza Powszechna, Warszawa.

Ustawa z 9 czerwca 2011 r. o wspieraniu rodziny i systemie pieczy zastępczej (tekst jednolity: Dz.U. 2011 nr 149 poz. 887).

\section{THE ROLE OF FOSTER CARE IN THE PROCESS OF SOCIALIZATION}

\section{Summary}

This article is devoted to an analysis of the foster care system, with particular consideration of its pro-social function. It contains the initial findings of field research into the foster care system. The most important are: 1) the division of family functions between the various participants is suboptimal and generates conflicts; 2) foster families lack social and organizational support; 3 ) biological parents are not motivated to improve their child-raising skills; 4 ) in the current situation the pro-social function of foster care is not performed, and thus foster care contributes to the reproduction of pathological phenomena.

\section{Key words / słowa kluczowe}

foster care / piecza zastępcza; social policy / polityka społeczna; sociology of the family / socjologia rodziny; functions of the family / funkcje rodziny; social pathologies /patologie społeczne 